\title{
Nem nacional, nem realmente artística, mas nem por isso desprezível: a Música Popular aos ouvidos de Mário de Andrade
}

André Domingues dos Santos ${ }^{a}$

\begin{abstract}
Resumo
Persiste uma visão bastante negativa na crítica a respeito da relação dos modernistas, sobretudo de Mário de Andrade, com a Música Popular. O presente estudo busca reavaliar a questão à luz dos escritos de Mário, explorando tanto as interlocuções internas do modernismo, quanto a produção crítica e a prática artística (em que se comenta uma obscura parceria de Mário de Andrade com o pianista Marcelo Tupinambá, "Canção marinha"). Bem menos do que uma recusa mecânica, observa-se no autor uma complexa operação eletiva de elementos para exaltação ou repúdio nas obras de artistas da Música Popular.
\end{abstract}

Palavras-chave: Modernismo, Nacionalismo, Música Popular, Mário de Andrade 
Um capítulo não inicial, mas valiosíssimo, na longa série de contatos entre a Literatura e a Música Popular brasileiras foi o contato que o modernista Mário de Andrade teve com a produção veiculada pelo rádio, pelos discos, pelos meios da cultura urbana, em geral. Não obstante ter sido o principal formulador da estética musical nacionalista que se tornou hegemônica a partir de 1924, com olhos voltados para a produção erudita e folclórica, ele foi também quem mais frequente e profundamente se debruçou sobre a chamada Música Popular, formulando um pensamento bastante perspicaz e original a respeito do tema. No entanto, surgiram críticos brasileiros e o injusto quase-consenso de que tivesse verdadeiro desprezo por essa produção (destaca-se a exceção de SANDRONI, 2004, p. 23-35). Seu emprego dos termos "popularesco" e "submúsica" tornaram-se chaves de tal tendência, sendo tomados como símbolos de uma recusa mecânica de toda a produção oriunda da cultura urbana de massa. Dentre os muitos exemplos das suas investidas contra manifestações desse tipo, tornou-se comum citar um trecho do artigo "Música popular", dedicado a um concurso de músicas carnavalescas assistido no Rio de Janeiro, em 1939:

O que aparece nesses concursos não é o samba de morro, não é coisa nativa nem muito menos instintiva. Trata-se, exatamente, de uma submúsica, carne para o alimento de rádios e discos. Elemento de namoro e interesse comercial com que fábricas, empresas e cantores se sustentam, atucanando a sensualidade fácil de um povo em via de transe. (ANDRADE, 1976b, p. 280-281)

Revendo outros comentários do autor sobre o que identificava como música popularesca ou submúsica, porém, nota-se que não eram necessariamente de repúdio, apresentando nuances mais ricas. Ainda mais, quando se associa tais artistas aos que chama de "semieruditos", frequentemente merecedores de generosos elogios. Assim, as discrepâncias de tratamento exigem uma reavaliação mais justa e abrangente a respeito do tratamento que deu à Música Popular. Há algo de arriscado nisso, visto que se trata de uma questão à qual o próprio autor não se propôs diretamente estudar - donde chegar a uma solução modelar podia ser, então, improvável. Vale a pena evocar, entretanto, a sensibilidade, a profundidade e a honestidade 
intelectual das reflexões de Mário para justificar a expectativa de se atingir uma formulação mais geral nessa empreitada.

Segundo a parcela da crítica que enfatiza o desprezo de Mário de Andrade pela música popular, sua postura seria fruto, em última instância, do impulso de busca e perpetuação do poder político-cultural da intelectualidade modernista-nacionalista. Esta teria ficado bastante mais confortável em manipular as fontes supostamente puras e ingênuas do folclore rural do que a instável e arredia cultura das cidades. É o que afirma, exemplarmente, o crítico literário-musical José Miguel Wisnik em "Getúlio da Paixão Cearense (Villa-Lobos e o Estado Novo)":

\begin{abstract}
Sintomática e sistematicamente o discurso nacionalista do Modernismo musical bateu nessa tecla: re/negar a cultura popular emergente, a dos negros da cidade, por exemplo, e todo um gestuário que projetava as contradições sociais no espaço urbano, em nome da estilização das fontes da cultura popular rural, idealizada como a detentora pura da fisionomia oculta da nação. (...) O problema é que o nacionalismo musical modernista toma a autenticidade dessas manifestações como base de sua representação em detrimento das movimentações da vida popular urbana porque não pode suportar a incorporação desta última, que desorganizaria a visão centralizada homogênea e paternalista da cultura nacional. (WISNIK, 1983, p. 133)
\end{abstract}

Nesse caminho, identificou-se um "vilão histórico" para responder pelo desprestígio - e pelo sintomático silêncio da pesquisa acadêmica - de que a Música Popular padeceu durante a maior parte do século passado: o Modernismo. E, dada a proeminência de Mário nas reflexões musicais do grupo, não raramente foi imputada a ele a maior responsabilidade pela violência, como se entrevê num argumento de Arnaldo Contier que começa por uma contextualização discutível:

Com a ampliação do sistema radiofônico e da indústria do disco, as músicas populares urbanas e sertanejas passaram a "incomodar" os artistas eruditos. (...) Na realidade, a indústria cultural, a música popular, não conseguiram ser discutidas histórica ou artisticamente pelos modernistas (CONTIER, 1992, p. 280).

O plural "modernistas", aí empregado, não deve enganar: o alvo principal era Mário de Andrade. Basta ver que o outro grande expoente musical modernista, Heitor Villa-Lobos, foi 
logo absolvido do incômodo descrito, em função seus trabalhos inspirados "nos choros e serestas dos artistas populares urbanos". A destinação mais aguda do juízo só aparece nos parênteses finais: "Os modernistas brasileiros temiam os ruídos e os sons oriundos da 'cidade que sobe' (São Paulo, por exemplo)" (Idem, Ib., p. 281).

Mais recentemente, José Geraldo Vinci de Moraes aprofundou o tom crítico à postura de Mário de Andrade, buscando, inclusive, seu reflexo no cotidiano musical paulistano (novamente, usando Villa-Lobos como contraexemplo):

É bastante conhecido o menosprezo de Mário de Andrade pela música "popular" produzida e divulgada na grande cidade e nos aparelhos eletrônicos, qualificada de inferior e sem importância para a configuração de outra, profundamente popular e nacional. As declarações do chorão "Barão" parecem reforçar essa sensação de desconsideração e menosprezo deixada por Mário de Andrade. De acordo com Barão, que o conheceu apenas indiretamente, Andrade nunca frequentou as famosas e tradicionais reuniões em sua casa e muito menos outras rodas de choro (fato corriqueiro, por exemplo, nas atividades de Villa-Lobos no Rio de Janeiro no início do século). Esses depoimentos servem para demarcar as preocupações de Mário de Andrade no campo da música popular brasileira, voltados essencialmente para o "folclore" ou "música nacional" e sua oposição àquela urbana "popularesca" e confirmar, na prática, suas posturas delineadas ardorosamente no seu texto "A música e a canção populares no Brasil". (MORAES, 2000, p. 109)

É certo que tal linha de pesquisa, incisiva na problematização da relação entre o modernismo e a Música Popular, tem se mostrado fértil. É certo, também, que diversos comentários de Mário podem corroborá-la. Contudo, a tendência não dá conta de muitos outros comentários dirigidos por ele às canções veiculadas por rádios e discos, cunhados com uma visão bem mais generosa, ampla e complexa. Um caso claro foi o de sua admiração pelo samba "Praça Onze", de Herivelto Martins e Grande Otelo, pelo o qual afirmou ficar "estrangulado" de comoção em carta a Moacyr Werneck de Castro:

Eu sempre espero que ainda apareça aquele homem excelente que estude a psicologia, as sublimações, desvios e o sofrimento da gente carioca, através das letras dessa coisa incomparável que são os textos de samba. Quando escutei pela primeira vez os cariocas gemendo com candura e obediência que "Vão acabar com a Praça Onze", fiquei horrorizado. (apud TONI, 2004, p. 279). 
Houve, inclusive, situações em que Mário partiu da ideia de submúsica para uma clara manifestação de simpatia, inclusive no primeiro parágrafo de "Música popular":

Nos primeiros dias deste mês deu-se enfim o grande concurso de lançamento das músicas para o próximo carnaval. E é sempre agradável pensar que, embora se trate de um gênero musical que, tal como foi apresentado, é uma espécie de submúsica, a festa atraiu nada menos que 300 mil pessoas. (...) Era de ver o pessoal do povo durante as execuções. Uma serenidade com muito de religiosa, em que o corpo mexia muito levemente, muito leve, esboçando discretissimamente o "passo", esse movimento indescritível, maior graça de um povo em férias, que será a principal razão de ser dessa cidade. (ANDRADE, 1976b, p. 279)

A urgência de se reavaliar a visão de Mário de Andrade sobre a Música Popular foi bem percebida por Juliana Perez Gonzalez, que analisou o uso dos termos 'música popularesca' e 'submúsica' nas obras do modernista. Seus levantamentos a levaram à conclusão de que ambos não portavam, necessariamente, traços de uma rejeição, tendendo 'popularesco' a designar o "feito à maneira do popular" (GONZALEZ, 2012, p. 133), tanto na cultura midiatizada quanto na arte erudita, e 'submúsica', o resultado de artifícios enganadores empregados para tornar uma música mais comercializável nos meios de comunicação modernos ou para angariar aplausos nas salas de concerto (Idem, Ib., p. 220-221). A argumentação manteve, portanto, a restrição à 'submúsica', identificando-a, apartadamente, como um procedimento mais geral de desvirtuamento artístico, ao passo que salvou a 'música popularesca' de uma carga necessariamente pejorativa, afirmando ser apenas a incompletude do popular:

Deixa-se para futuras pesquisas a especulação a respeito da carga pejorativa atribuída ao conceito música popularesca seja uma construção histórica e não uma particularidade do pensamento musical de Mário de Andrade, pois (...) observou-se que seu uso não se restringiu a qualificar a música popular urbana, mas também algumas peças de procedência erudita, todas apreciadas por ele. Possivelmente o desdém com que alguns dos seus contemporâneos contemplaram a música midiatizada seja o primeiro responsável pela distância que se encontrou nos escritos de Mário de Andrade e o uso do termo na historiografia musical brasileira. Não obstante, o 
escritor modernista expressou um forte desprezo por um tipo de música que denominou como submúsica, aquela que considerou como sendo de ínfimo valor por apelar para recursos fáceis a fim de ganhar a aceitação rápida do público, e que encontrou tanto nos teatros e em seus músicos virtuosos quanto no rádio e nos discos. (GONZALEZ, 2012, p. 237)

É, sem dúvida, uma leitura aguda e pertinente, mas, em sua busca por uma formulação geral, acaba deixando irresolvida não só a referida construção histórica da carga pejorativa do termo 'popularesco' na obra de Mário de Andrade ${ }^{1}$, mas também uma outra importantíssima questão: como se estabelecer de forma apenas aproximativa uma distinção conceitual tão relevante quanto essa entre 'submúsica' e 'música popularesca', no interior da obra de um autor notoriamente zeloso, quase obsessivo, pelo rigor conceitual? A questão torna-se ainda mais problemática se forem consideradas as ocasionais observações simpáticas do autor a produtos de submúsica, como se fez há pouco, na citação do emblemático artigo "Música popular". É preciso, pois, encontrar outro caminho para a questão.

1 O sentido mais preciso de música popularesca seria o de algo que se popularizasse, mas por artifício, não em função das necessidades psicossociais do povo. Esse sentido ultrapassa a existência ou não de uma indústria cultural e pode ser relativo a uma força exógena como a da igreja, como se passa com os pastoris, os vilhancicos portugueses e os demais cantos de natal europeus: "São peças religiosas eruditas impostas ao povo pela classe eclesiástica - peças sabidamente de autor, e que, como peças, quase nunca conseguem se popularizar folcloricamente. Tipo de fato popularesco, mas não exatamente popular" (ANDRADE, 1976b, p. 343).

\section{Popularescos, submúsicos e semieruditos}

Antes de seguir a investigação sobre a possível posição da Música Popular na obra de Mário de Andrade, vale a pena lembrar que as dificuldades em lidar com tal conceito não foram exclusivas do autor e nem, sequer, da intelectualidade modernista, mas de toda cultura da época (SANDRONI, 2004,p. 26). Além de não haver um suficiente amadurecimento conceitual do campo popular em seu tempo, é preciso lembrar que Mário conheceu um meio musical paulistano em que a Música Popular e o chamado "folclore" ainda se misturavam e contaminavam bastante reciprocamente. O supracitado estudo de José Geraldo Vinci de Moraes foi rico em exemplos nesse sentido, como no caso do violeiro Sorocabinha, que não se adaptou ao cotidiano da indústria cultural e resolveu se retirar para um sítio no interior, ou no do cantor e compositor Paraguaçu, que concentrou parte importante de seu trabalho na adaptação de canções folclóricas. Tais exemplos repercutiam no campo musical um paradoxo que São Paulo vivia em todo o plano social até os anos 30 do século passado: 
2 A ideia de falta emerge, também, na acusação de baixa destinação psicossocial, representada pelo sensualismo, com seu efeito dinamogênico restritivo, tantas vezes abominado por Mário. No texto citado, aliás, há um trecho que sinaliza mais diretamente para o efeito restritivo do sensualismo popularesco: "Há sempre que se entristecer com esse talvez mal sintoma, diante da boçalidade ou da sensualidade meramente exterior de certas peças carnavalescas" (ANDRADE, 1976b, p. 280).
Se não há como negar que [São Paulo] ingressara definitivamente, como vimos, na frenética cadência das metrópoles modernas, não se podem deixar de notar os resquícios da pequena e provinciana cidade ruralizada que ela ainda guardava. (MORAES, 2000, p. 143)

A falta de um aparato teórico e de um campo de observação bem definidos, no entanto, não impediram que Mário de Andrade percebesse e, em boa medida, individualizasse o fenômeno da Música Popular. No próprio artigo “Música popular", havia uma série de características elencadas da "submúsica" que bem podiam servir, se não como definição, como uma boa delimitação do que seria posteriormente chamado de Música Popular, a começar pela presença marcante da mídia moderna e comercial (rádio e discos) na produção e na divulgação dessa música e, na outra ponta, a presença da massa urbana como receptora e consumidora dos produtos gerados. A esses elementos é interessante agregar, ainda, a instabilidade de suas características musicais, em função de ser destinada ao consumo e, logo, submetida à flutuação dos modismos (ANDRADE, 1976b, p. 282).

O mesmo texto "Música popular" apontava outras duas características básicas dos artistas de submúsica: a origem urbana da cultura em que se formavam (dada a sujeição a "todas as instâncias e aparências culturais da cidade", com seu cosmopolitismo) e o escasso conhecimento musical ou poético (ignorância estendida, inclusive, aos seus admiradores e críticos, ironizados como "doutores em sambice"). Os dois elementos são fundamentais por revelarem uma incompletude essencial desses artistas: nem podiam ser considerados verdadeiramente populares, folclóricos, por falta da vivência tradicional que funda a arte fatalizadamente nacional, nem podiam ser considerados produtores de arte universal, por falta do conhecimento da técnica erudita (e note-se que o domínio da técnica universal e a expressão pura do nacional são, justamente, os dois quesitos de valoração artística mais prezados na estética musical marioandradiana). Daí, pode-se inferir que sua qualificação dessa produção como 'submúsica' se devesse, antes de tudo, ao duplo déficit no plano ontológico da estética musical ${ }^{2}$. 
3 Um bom exemplo dessa eleição de qualidades pontuais e matizadas se encontra, novamente, no texto "Música Popular": "Vez por outra, mesmo nessa submúsica, ocasionalmente ou por conservação de maior pureza inesperada, aparecem coisas lindas ou tecnicamente notáveis" (ANDRADE, 1976b, p. 281)

4 Esse texto não deixa dúvidas quanto ao ponto de partida no universo da cultura consumida na cidade. Seu parágrafo inicial é eloquente: "Na evolução da música popular urbana do Brasil teve grande importância o trabalho de uma mulher, já esquecida em nossos dias, Francisca Gonzaga. Este esquecimento, aliás, é mais ou menos justificável, porque nada existe de mais transitório, em música, que essa espécie de composição. Compor música de dança, compor músicas para revistas de ano e coisas assim é uma espécie de arte de consumo, tão necessária e tão consumível como o leite, os legumes, perfume e sapatos. O sapato gasta-se, o perfume se evola, o alimento é digerido. E o samba, o maxixe, a rumba, depois de cumprido seu rápido destino de provocar várias e metafóricas... calorias, é esquecido e substituído por outro. E como o artista só vive na função da obra que ele mesmo criou, o compositor de dança, de canções de rádio, de revista de ano, também é usado, gastado, e em seguida esquecido e substituído por outro" (ANDRADE, 1976b, p. 329).
Dada a predominância da noção de falta, o eixo determinante das ressalvas de Mário de Andrade contra aquela submúsica do rádio e dos discos não era, então, um mero preconceito e nem um desprezo a priori, mas a constatação de uma incompletude estética diante das exigências de enraizamento folclórico e domínio da técnica erudita. Assim, outros adjetivos que designam a falta, como 'música popularesca' ou 'música semierudita', se irmanariam à submúsica num mesmo status ontológico, apenas com ênfase valorativa distinta: a primeira por ser não completamente nacional e a segunda por ser não ainda universal. Não por acaso, quando Mário comentava seu interesse eventual por músicas populares que mereciam tais designações, não se percebe na motivação dos elogios uma apreciação orgânica da obra em questão, mas algo pontual e avaliado por maiores teores de brasilidade ou níveis de invenção técnica ${ }^{3}$.

A interpretação aqui proposta, com a equiparação ontológica de submúsica, música popularesca e semierudita, tem a vantagem de não postular um Mário de Andrade subitamente relapso de seu notório rigor formal ou relaxado de seu igualmente famoso afã classificatório. Não constituindo uma forma estética, em si, essa música não requeria uma conceituação precisa, ficando bem expressa por adjetivos que designassem a incompletude. Não seria de se estranhar, portanto, que Mário os empregasse sem muita distinção. Foi o que aconteceu, por exemplo, no artigo sobre a pianista Chiquinha Gonzaga, em que a situou no processo de evolução das danças urbanas nacionais ao lado de Ernesto Nazareth, mas sem usar a qualificação de semierudita que empregou a Nazareth num texto em que também os irmanou (ANDRADE, 1976b, p. 323), preferindo o termo "popularesca":

A invenção de Chiquinha é discreta e raramente banal. Ela pertence a um tempo em que mesmo a composição popularesca, mesmo a música de dança e das revistas de ano ainda não se degradaram cinicamente, procurando favorecer apenas os instintos e sensualidades mais reles do público, como hoje. (ANDRADE, 1976b, p. 331) ${ }^{4}$

Para reforçar conceitualmente a condição singular e irmanada de submúsica, música popularesca e semierudi- 
ta, porém, é interessante rever a distinção das três técnicas artísticas descritas por Mário no capital texto "O artista e o artesão". A primeira manifestação, a do artesão, seria "a única verdadeiramente pedagógica, o aprendizado do material com que se faz a obra de arte" (ANDRADE, 1963, p. 14). Prevalecia, nela, um princípio de utilidade que quase anulava a invenção individual em função das necessidades de uso coletivas. Seu melhor exemplo seria o dos artesãos do Egito antigo (citando o egiptólogo Gaston Maspero), com sua uniformidade assombrosa: “O temperamento pessoal do indivíduo não se revela, senão por detalhes de fatura quase imperceptíveis, e quem quer estude por alto a arte egípcia nada mais percebe que essa noção de impersonalidade coletiva" (ANDRADE, 1976, p. 16). Dado esse sentido coletivo, era flagrante sua proximidade com o folclore, em que a memória inconsciente da raça, mais do que a criatividade o indivíduo, seria a verdadeira produtora da arte. Lembra, assim, a estimada figura do cantador Chico Antônio, do texto Vida do Cantador, que "improvisava a imensa alma nordestina, renascida dentro dele" (ANDRADE, 1993, p. 38).

A segunda manifestação descrita seria a efetivamente desprezada demonstração de virtuosismo, que também não parece remeter à música popularesca e semierudita. Afinal, é qualificada como "o conhecimento e prática das diversas técnicas históricas da arte", ou seja: um derivado vazio da erudição. Seria, logo, algo muito distante da ignorância formal dos popularescos e não alcançado pela formação incompleta dos semieruditos. Sua destinação psicossocial até se aproximava da submúsica, na medida em que se desviava de uma arte idealmente desinteressada, dirigindo-se "à sensualidade do aplauso ignaro" (ANDRADE, 1963, p. 14-15). Sua cristalização habitual, porém, eram o "passadismo" ou o "academismo", posturas que nada tem a ver com "Praça Onze" ou as polcas de Chiquinha Gonzaga.

Já a terceira manifestação, a da solução ou invenção pessoal, seria distinta das demais porque não se prendia ao caráter imitativo e inconsciente da primeira e nem almejava o exibicionismo individualista da segunda. Seu processo era a consciente atividade de pesquisa da beleza, algo cada vez mais importante na modernidade, tempo em que "[a beleza] pesquisada por si mesma, se tornou essencialmente objetiva e 
experimental, materialista por excelência, para não dizer por exclusividade" (ANDRADE, 1963, p. 20). Tal pesquisa, porém, só era legítima quando não se fazia anarquicamente, com um vaidoso e tautológico princípio de pesquisar por pesquisar, mas com moralidade social e respeito às regras do artesanato fundamental (em que se incluíam a técnica universal derivada do material e a memória da raça), de maneira que seu resultado era necessariamente nacional, em particular, e humano, em geral. $\mathrm{O}$ artista sujeito de tal manifestação acabava sendo, assim, o músico erudito de vanguarda nacionalista, o único a reunir todas as competências necessárias para a criação.

Como se nota, nenhuma das três categorias correspondia à submúsica, à música popularesca ou à semierudita, o que leva a considerá-las, novamente, como uma mera falta, incompletude: não era mais artesanato e não chegava a ser arte plenamente.

\section{Heróis acidentais}

Não sendo uma manifestação específica, a produção popularesca e semierudita não tinha uma função social determinada a priori no pensamento estético de Mário de Andrade. Entretanto, frequentemente fazia uma importante função de intermediação entre o popular e o erudito nos seus estudos de evolução da música brasileira, algo também notado por Gonzalez:

Mário de Andrade conferiu um papel importante aos músicos populares urbanos enquanto mediadores entre a música popular de raiz folclórica e a música erudita, papel que ajudava a completar sua visão da relação entre o popular folclórico e o erudito, que sempre lhe interessou. (GONZALEZ, 2012, p. 214).

Seria precipitado elevar tal intermediação a um papel social singular, o que exigiria uma definição precisa de Música Popular. Mais correto seria observar que tal função foi desempenhada por circunstâncias históricas, mas de forma tão preponderante no processo de trocas culturais da formação brasileira que suscita uma apreciação mais cuidadosa. $\mathrm{O}$ exemplo melhor acabado foi o do último texto de crítica musical escrito por Mário, "Cândido Inácio da Silva e o Lundu”, em que 
analisou o referido compositor e cantor oitocentista. Primeiro, tratando das modinhas, Mário afirmou:

Embora acentuadamente "de salão" e semieruditas, com algumas dificuldades de enfeites e emissão vocal, parece mesmo que as modinhas dele se desnivelaram rapidamente e se difundiram no seio popular. (ANDRADE, 1999)

Tal passagem do nível semierudito para o popular seria a segunda parte da rara e grande migração da modinha erudita para o nível folclórico: primeiro aos salões da burguesia, ambiente de Cândido, e só, então, ao povo. O mecanismo de tal intermediação seria o desnivelamento, conceito tomado de Charles Lalo e desenvolvido em diálogo crítico com Roger Bastide, cujo funcionamento consistia num processo de dominação em que determinada manifestação cultural "parte do mais forte [a elite] para se arraigar e tradicionalizar no mais fraco [o povo]" (ANDRADE, 1976b, p.340). A desigualdade das partes envolvidas no processo não vinha tanto ao caso, já que era um fato histórico consumado na formação nacional. Foi o resultado que mobilizou Mário para uma série de dúvidas: teria se completado esse processo rumo à assimilação da cultura erudita à inconsciência coletiva e ao folclore nacional? Relutante em afirmar que a modinha tivesse efetivamente se tornado folclórica, o autor defendia a ideia de que o processo ainda não havia se concluído, já que "o povo frequentemente adota uma melodia erudita, mas não consegue lhe surpreender a forma nem as fórmulas, e torná-la uma constância esquemática de criação" (ANDRADE, 1976b, p. 348).

A dificuldade em se completar o desnivelamento da modinha, de toda forma, não desmerecia o papel do semierudito na intermediação. Contudo, mais do que as modinhas desniveladas, o grande motivo da admiração de Mário por Candido foi a canção "Largo da Sé", identificada como marco inicial da nacionalização do primeiro gênero musical afro-brasileiro, o lundu.

O lundu, e por causa dele o Lá no Largo da Sé de Cândido Inácio da Silva, assume uma importância histórica e sociológica bem grande na formação da sociedade brasileira e sua música. É a primeira forma musical que adquire foros de nacionalidade. Não é branco mas já não é negro mais. É nacional. (ANDRADE, 1999, p. 228) 
O lundu, nesse caso, representou uma subida de nível (subida, do ponto de vista do jogo social de forças, é bom dizer), indo de um setor popular à elite e, então, ao popular em geral. O semierudito, outra vez, funcionou como instância intermediária para se atingir o nacional. Algo semelhante se encontra no texto "Música brasileira":

É só quando a música anônima do povo principia se impondo em suas formas e suas peças, pela originalidade já mais ou menos nacional, em pleno Império, que os compositores semieruditos principiam se aproveitando dela na temática das suas quadrilhas e polcas, que coincidiam na rítmica com o binário do povo nacional. E só ainda mais tarde é que estourará na música erudita e dentro de uma forma erudita, o “Samba”, de Luiz Levi (sic). (ANDRADE, 1976b, p. 357)

Essa função intermediadora do semierudito, por mais alastrada que tivesse sido, não era uma exigência lógica do pensamento marioandradiano. Ao se ler elogio feito aos semieruditos no trecho citado acima, é preciso notar, ainda, que o argumento trazia uma ressalva contra a lentidão dos eruditos em se aprofundar no nacional. Da mesma forma, quando Mário atribuía a criação de Cândido à "espontaneidade do sangue e do convívio" (ANDRADE, 1999, p. 222), tratava-se de uma forma de diferenciá-lo de um erudito que chegasse a um resultado igualmente nacional, mas com bases em séria pesquisa folclórica ${ }^{5}$. Daí que se possa afirmar com segurança que, para Mário, o importante o papel nacionalizador dos semieruditos (e de artistas da música popular, em geral) tivesse sido historicamente central, na falta de eruditos que o fizessem. A lógica desse pensamento não deixa dúvidas de que a tarefa de nacionalização da arte coubesse primeiramente aos eruditos, como no Ensaio Sobre a Música Brasileira:

Uma arte nacional não se faz com escolha discricionária e diletante de elementos: uma arte nacional já está feita na inconsciência do povo. O artista tem só que dar pros elementos já existentes uma transposição erudita que faça da música popular música artística. (ANDRADE, 1976a, p. 15-16)

5 O texto, aliás, reitera a inexistência de vínculo de Cândido Inácio da Silva com o folclorismo em diversos momentos. Cf.: ANDRADE, 1999, p. 219, 221-223. 
leva a concluir, com Wisnik, que, no pensamento de Mário de Andrade, na atuação de Villa-Lobos e no ideário modernista, em grande medida, o intelectual nacionalista buscava decididamente se impor no comando estético-político das ações:

\begin{abstract}
Através dessa curiosa operação desalienante, em que o povo recobra o "caráter" que lhe falta, o intelectual letrado-pedagogo fica no centro imaginário, de onde procura reger o coro nacional, levando-o à unidade harmônica. Seu papel aparentemente modesto de simples correia conversora (do popular primário ao popular estetizado) é exponencial porque comanda idealmente a passagem da sociedade passiva à sociedade ativa, ou seja, porque comanda a parte mais secreta e decisiva - a psicossocial - do processo político. Ele aparece de modo subjacente como o orquestrador da sociedade dividida (é nesse campo devidamente preparado que vai se erguendo a figura singular de Heitor Villa-Lobos) (WISNIK, 1983, p. 146).
\end{abstract}

O sentido político do posicionamento de Mário acusado por certa parcela da crítica fica aqui preservado, mas com uma divergência quanto à forma como se deu, negando o menosprezo ou medo da música popular. Mário propunha uma arte política e combativa, sem dúvida, mas o grande inimigo a bater definitivamente não andava entre Sinhô, Carmen Miranda ou Chiquinha Gonzaga.

\title{
Parceria obscura
}

Uma obra reveladora do complexo tratamento dado por Mário de Andrade à música popular é a única e curiosíssima parceria que estabeleceu nesse campo, "Canção marinha", criada com o compositor e pianista Marcelo Tupinambá em 1925. Trata-se de uma obra obscura, embora registrada em disco comercial por Edgard Arantes em 1930. No meio musical, sua única repercussão representativa foi uma regravação em 1969 pela cantora, compositora e folclorista Inezita Barroso, no álbum Recital $n^{\circ} 2$. No meio literário, por outro lado, passou tão despercebida que ficou ausente da coletânea Poesias, organizada por Mário de Andrade em 1941, assim como do extenso volume póstumo Poesias Completas, de 1955, planejado em vida pelo autor. Mesmo cercada por silêncio, entretanto, essa canção guarda o testemunho do intercâmbio (e do jogo 
de tensões) entre eruditos e populares no modernismo. Eis o poema que a originou:

Tantos peixinhos nas águas,

Tanta escama dos peixinhos!

No coração tantas mágoas,

Das mágoas tantos espinhos.

A alegria que aparece,

Foge depois, nem se vê;

Também a onda brota, cresce,

Morre... sem saber porquê.

Por mais que a tristeza escondas,

Nunca a escondes muito bem,

É como o sulco das ondas,

Surge ora aqui, ora além.

Prazer que mais se deseja,

Quanto mais custoso e incerto,

Espuma branca que alveja,

Mais de longe que de perto!

Na vida só brotam mágoas,

No mar bolhas entre escolhos,

Há olhos de luz nas águas,

Há luzes de água nos olhos.

É necessário se especular sobre a origem desse poema de história desconhecida. Há sinais de que Mário o tenha escrito especialmente para Tupinambá, que vinha pedindo poemas para amigos, ou que, no mínimo, tenha imaginado um destino extraliterário para tal escrito, pois, como se disse, nunca o incluiu nas suas antologias poéticas. Além disso, imprimiu nele traços marcantes de um diálogo com o universo da canção popular, a começar pelo o título, dado em referência direta à música. A métrica regular é outro desses sinais, feita num metro comum da cultura popular oral, o heptassílabo, com uso sistemático de consonâncias tradicionais, tais como as repetições de palavras e as rimas intercaladas do final dos versos (vale dizer: recursos que ele não usou uma única vez em seu livro de poemas imediatamente anterior, o clássico Pauliceia Desvairada, de 1922). Mais um traço significativo é a busca por 
uma linguagem simples em vocabulário, semântica e sintaxe, afinada às experiências elementares do amor e da natureza. É de se notar, nesse sentido, que a analogia entre a enganosa aparência do mar e a ilusória felicidade da vida foi didaticamente conduzida em direção à poderosa metáfora final, "Há olhos de luz nas águas/ Há luzes de água nos olhos", cujo significado não exige qualquer erudição para ser compreendido.

Sobre esses versos, Tupinambá escreveu uma canção quaternária, de andamento moderato, com harmonia restrita às funções básicas de tônica e dominante e forma A-B-A, sendo a primeira parte em Mi Menor e a segunda, no tom relativo de Sol Maior. A escolha da forma é algo que imediatamente chama a atenção, visto que o poema, por seu comprimento estrófico de dois blocos de oito versos e um de quatro, sugeria algo como A-A-B. A opção pela forma A-B-A, desdobrando quatro versos em oito frases musicais na parte final, foi inusitada. Essa aparente violência contra a forma, sem dúvida, pode ter desagradado ao poeta, mas o pouco apreço que dedicou à canção tem causas mais profundas. Acontece que Mário, grande entusiasta dos famosos tanguinhos de Tupinambá, recebeu mal a série Canções Brasileiras, em que veio "Canção marinha".

A estreia das Canções Brasileiras, toda feita com poemas musicados de autores contemporâneos, deu-se em 3 de fevereiro de 1924, no Salão Germânia, em São Paulo, num recital que teve a voz de Edgard Arantes e o piano do próprio Tupinambá. Segundo comentários de época recolhidos por Benedicto Pires de Almeida, o sucesso foi estrondoso, seja na música, "merecedora de todo o interesse e elogio", seja na aceitação da "refinada" plateia, pois os artistas "foram insistentemente aplaudidos, tendo de voltar várias vezes ao proscênio" (ALMEIDA, 1993, p. 30-34). Na contramão desse entusiasmo, entretanto, a reação de Mário foi de "enorme desilusão":

Esperava ouvir obras já de caráter menos artisticamente elementar (a própria escolha dos poetas musicados denunciava essa preocupação), mas caracteristicamente nossas, caracteristicamente brasileiras. As obras anteriores do artista permitiam essa esperança. Me desiludi.

Os poucos trechos vocais ouvidos [Mário não ficou até o final do recital] tinham feição vaga, tímida, indecisa, sem nada de positivamente raçado, como nas peças de dança do artista. Sem dúvida, eu não pedia que Tupinambá fizesse, 
nessa tentativa de dar torneio mais trabalhado, mais artístico (...) à maneira nacional de cantar, fizesse unicamente canções de dança, maxixes e candomblés. Porque não me esquecerei que muita canção existe sem ser de dança, e que o lundu e a modinha não são maxixes. Mas nesse terreno do lundu, da modinha, da canção, muito era de esperar do artista, principalmente porque o que o notabiliza não é propriamente a riqueza da invenção rítmica nossa, como em Nazaré. (...) O que faz notável Tupinambá é a riqueza de invenção melódica brasileira, que nem mesmo Nazaré possui tão bela e tão patrícia. Aquela dolência caprichosa, lânguida; aquela sensualidade trescalante, opressiva, quase angustiosa; aquela melancolia das vastas paragens desertas; aquele deserto, digamos assim, da linha melódica brasileira; e de quando em quando o arabesco inesperado; alerta a vivacidade espiritual do caipira, a inteligência aguda, o burlesco repentino herdado dos negros, que tudo isso na cantiga nacional se revela: desapareceram das canções de Tupinambá. Deram lugar a uma melodia incolor, muitas vezes banhada de vulgaridade. Um músico de firme educação dizia-me desapontado: são canções de qualquer país. Não é bem isso. Mas com tendência meio pronunciada para o fado, é certo que Tupinambá, nestas melodias, titubeou, criou trechos agradáveis talvez para ouvidos fáceis, mas tímidos, sem firmeza, dum arabesco muito pouco brasileiro, perdidos. Sem dúvida não irei até a negar que de longe em longe uma pincelada mais eficiente revela o Brasil naqueles trechos vocais. Mas não são brasileiros. O mais que se poderá dizer é que são canções escritas por brasileiro. (ANDRADE, 1976b, p. 116-117)

A acusação de falta de brasilidade estava, sem dúvida, embasada na densa teoria musicológica nacionalista de Mário de Andrade, mas não era assumida por Marcelo Tupinambá. Ao contrário: o autor considerava que suas canções eram um ato de construção de uma cultura autenticamente nacional, por exemplo, quando afirmou:

Um dia, resolvi tentar nova vida em São Paulo e deixando em segundo plano a engenharia, comecei a compor músicas, revistas e canções tirando-as da dolência enfermiça das toadas africanas, herança da primeira colonização. A poesia e a música dos nossos geniais poetas e compositores eram dois mananciais para a minha obra (ALMEIDA, 1993, p. 86).

Tal tentativa autônoma de equacionar o caldeamento racial brasileiro e a exaltação dos poetas e músicos eruditos 
6 Note-se, aqui, a incompletude do substantivo "semicultura" significando, novamente, o imperfeito universo da cultura popular urbana. não sensibilizaram o amigo Mário de Andrade, que continuou admirando Tupinambá apenas em tangos, maxixes e ritmos interioranos. O compositor ficava, dessa forma, numa posição muito próxima da de Catulo da Paixão Cearense, que era aplaudido por Mário nas canções sertanejas (nas que lhe soassem autênticas, vale frisar) e deplorado naquilo que parecia emulação do folclore ou da arte culta. A semelhança dos dois, aliás, foi observada pelo próprio Mário numa crítica à estreia das Canções Brasileiras, publicada na Revista do Brasil, em que dizia: “Tupinambá e Catulo são dois gênios que a celebridade está desencaminhando. Voltem os filhos pródigos à casa paterna! Não escutem os maus conselhos da semicultura!" (apud LEANDRO, 2005, p. 118) ${ }^{6}$.

É difícil precisar musicalmente o que Mário de Andrade dizia sentir falta nas canções de Marcelo Tupinambá, como "aquela dolência caprichosa, lânguida" ou "o burlesco repentino herdado dos negros", mas é certo que buscava uma característica que tais obras realmente não tinham: a raiz folclórica. Sintomaticamente, os dois contraexemplos que o musicólogo oferecia para a produção de Tupinambá eram desse tipo: a modinha rural "Casinha pequenina", de compositor anônimo, e o canto indígena "Nozani-ná Ore Kua", recolhido por Roquette Pinto junto aos índios Parecis do Mato Grosso (e que foi aproveitada diversas vezes por Heitor Villa-Lobos, como no "Choros n 3 Pica-pau"). As canções de Tupinambá, por outro lado, traziam um pensamento musical elaborado, embora não erudito, tendo elementos sofisticados, tais como as simetrias de fraseado de "Canção marinha" e o engenhoso recurso imitativo do movimento de uma onda usado no final da primeira estrofe. A própria opção de Tupinambá por um intérprete lírico, inclusive, já indicava, de antemão, um desejo de se distanciar do universo do folclore.

Mesmo com reação tão adversa às canções, porém, Mário de Andrade autorizou a composição de Marcelo Tupinambá. A obra foi exibida em 16 de janeiro de 1925, também no Salão Germânia, junto à segunda parte das Canções Brasileiras, tendo como cantor o barítono Sílvio Vieira. Dessa vez, Mário não se pronunciou.

A restrição às Canções Brasileiras de Marcelo Tupinambá não foi exclusividade de Mário de Andrade entre os literatos 
modernistas, chegando ao poeta Manuel Bandeira, que também teve versos musicados na série. Menos ácido do que o amigo paulista, Bandeira lamentou o aspecto "estilizado" de tais obras, mostrando perceber que se tratava de um tipo de composição feito sem a espontaneidade natural da cultura popular (apud LEANDRO, 2005, p. 117). Tal apreciação é significativa e permite ultrapassar um eventual caráter pessoal no julgamento de Mário, na medida em que vinha de alguém igualmente relevante e que tinha uma experiência mais avançada e bem sucedida de intercâmbio com músicos populares, em função da proximidade com o violonista e compositor Jayme Ovalle - em carta de dezembro de 1925, Bandeira anunciava exultante: "Eu e o Ovalle fizemos um choro de carnaval que é um sonho!" (apud WERNECK, 2008, p. 76). Essa relação, aliás, reflete diretamente a de Mário e Tupinambá. O paraense Ovalle, afinal, foi intensamente admirado naqueles meados dos anos 20 pelos dois modernistas, que se deliciavam com sua sensibilidade e imprevisibilidadee, tratando-o como um manancial bruto e direto da alma brasileira. Ao mesmo tempo em que até declaravam querer ser o próprio Ovalle, porém, mantinham uma reveladora distância em termos artísticos, clara na carta em que Mário afirmou:

O que fica mesmo por enquanto de bem firme na minha opinião é que nunca vi incapacidade criadora artística maior que a dele. Digo artística porque no pasticho musical popular (ele não é popular e daí a palavra pasticho) ele atinge a coisas não tem dúvida que estupendíssimas (apud WERNEK, 2008, p. 78).

Em resposta, Bandeira reforçou a opinião do amigo:

A tua ficha do Ovalle está estupenda (...). Você não sabe certos cães muito inteligentes, muito afetuosos, quando começam a olhar fixo pra gente, ganindo dolorosamente? Querem falar e não podem. O Ovalle me dá essa impressão. (apud WERNEK, 2008, p. 80)

A soma do "pasticho musical popular", que não era autenticamente popular, com a incapacidade de expressão artística (a falta da técnica erudita e do princípio da criação desinteressada), situavam Jayme Ovalle exatamente na esfera de submúsica, semicultura, semierudição ou música popularesca, partilhada 
por Marcelo Tupinambá, Ernesto Nazareth, Chiquinha Gonzaga, Catulo da Paixão Cearense e outros artistas populares urbanos. A relação de Manuel Bandeira e Mário de Andrade com ele, na mesma época em que Tupinambá fazia suas canções, reitera que o tratamento heterogêneo de admirações e rejeições eletivas não era fruto de alguma idiossincrasia pessoal, mas da própria forma como parte importante da intelectualidade modernista tomava a Música Popular. Compreende-se, então, porque Bandeira não se desinteressou por Ovalle, ante uma apreciação tão cáustica, e nem Mário rompeu com Tupinambá, desencaminhado pelas canções apátridas. Sem compromissos com uma apreciação orgânica, os modernistas salvavam elementos autênticos (oportunamente escolhidos) e repudiavam os "desvios", mantendo-se, de toda forma, na regência da representação da brasilidade.

\section{REFERÊNCIAS}

ALMEIDA, Benedicto Pires de. Marcelo Tupinambá. São Paulo: edição do autor, 1993.

ANDRADE, Mário de. Candido Inácio da Silva e o Lundu. Latin American Music Review, Vol. 20, $\mathrm{n}^{\circ}$ 2. University of Texas, 1999, p. 213-233.

O artista e o artesão. In: . O baile das quatro artes. São Paulo: Martins, 1963, p. 9-33. . Ensaio Sobre a Música Brasileira. São Paulo: Martins, 1976. Música, Doce Música: Estudos da crítica e folclore. $2^{\mathrm{a}}$ Edição. São Paulo: Martins, 1976b. . Vida do Cantador. Edição Crítica de Raimunda de Brito Batista. Belo Horizonte-Rio de Janeiro: Villa Rica, 1993. ARANTES, Edgard. Canção Marinha (M. Tupinambá/M. de Andrade) - disco de 78 rpm. Rio de Janeiro: Grav. Brunswick, 1930. Reproduzido em: < http://acervo.ims.uol.com.br/player/ SophiaSLPlayer.asp >. Acessado em: 04 nov. 2013.

CONTIER, Arnaldo. Modernismos e Brasilidade: Música, utopia e tradição. In: NOVAES, A. (org.): Tempo e História. São Paulo: Companhia das Letras, 1992, p. 159-287. 
GONZALEZ, Juliana Perez. Da música folclórica à música mecânica: uma história do conceito de música popular por intermédio de Mário de Andrade (1893-1945). 2012. 276 f. Dissertação (Mestrado em História Social). Faculdade de Filosofia, Letras e Ciências Humanas. Universidade de São Paulo, São Paulo, 2012.

LEANDRO, Marcelo Tupinambá. A criação musical e o sentido da obra de Marcello Tupynambá na música brasileira (1910-1930). 2005. 173 f. Dissertação (Mestrado em Musicologia). Escola de Comunicações e Artes. Universidade de São Paulo, São Paulo, 2005.

MORAES, José Geraldo Vinci de. Metrópole em Sinfonia: História, cultura e música popular na São Paulo dos anos 30. São Paulo: Estação Liberdade, 2000.

SANDRONI, Carlos. Adeus à MPB. In: CAVALCANTI, Berenice, STARLING, Heloísa \& EISENBERG, José (org.). Decantando a República, vol. 1: Inventário histórico e político da moderna canção popular moderna brasileira. Rio de Janeiro: Nova Fronteira; São Paulo: Fundação Perseu Abramo, 2004, p. 23-35. TONI, Flávia. A Música Popular na Vitrola de Mário de Andrade. São Paulo, Senac, 2004.

TUPINAMBÁ, Marcelo; ANDRADE, Mário de. Canção Marinha (partitura).

WERNECK, Humberto. O santo sujo: a vida de Jayme Ovalle. São Paulo: Ed. Cosac Naify, 2008.

WISNIK, José Miguel. Getúlio da Paixão Cearense: Villa-Lobos e o Estado Novo. In: SQUEFF, Enio; WISNIK, José Miguel. O Nacional e o Popular na Cultura Brasileira - Música. $2^{\mathrm{a}}$ edição. São Paulo: Ed. Brasiliense, 1983, p. 129-191. 


\section{Abstract}

Neither national, nor really artistic, but by no means negligible: the Popular Music to Mario de Andrade's ears

It remains a very negative view on critics about the relationship of the modernists, especially Mário de Andrade, with the Popular Music. This study aims to review the matter in the light of Mario's writings, exploring both internal dialogues of modernism, critical production and artistic practice (in this case, commenting an obscure partnership between Andrade and the pianist Marcelo Tupinambá, "Canção marinha"). Far less than a mechanical refusal, the author creates a complex elective operation of elements for exaltation or rejection in the works of artists of Popular Music.

Key-words: Modernism, Nacionalism, Popular Music, Mário de Andrade 